\title{
BERTAHAN DENGAN LUPUS: GAMBARAN RESILIENSI PADA ODAPUS
}

\author{
Anggun Resdasari Prasetyo, Erin Ratna Kustanti
}

Fakultas Psikologi Universitas Diponegoro

J1. Prof Sudharto SH, Tembalang, Semarang 50275

anggun.resdasari@gmail.com

\begin{abstract}
Lupus is a chronic, autoimmune disease in which an abnormal immune system can cause inflammation on several organ or body systems. The risk of mortality rate caused by Lupus is high and late diagnosis is also prevalent which impact the psychological aspect of individual affected with Lupus (so-called Odapus). Therefore, resiliency is needed; that is individual ability to survive and keep optimistic attitude towards recovery. This study aims to describe the resiliency of the affected individuals with Lupus. This is a qualitative study. Eight persons affected with Lupus who were still coping with Lupus participated in this study. The results indicated that subjects developed a negatives constructs to adapt with Lupus. Therefore, psychological intervention is needed to improve their resiliency.
\end{abstract}

Keywords: Lupus, resiliency

\begin{abstract}
Abstrak
Penyakit Lupus merupakan penyakit autoimun kronis dimana terdapat kelainan sistem imun yang menyebabkan peradangan pada beberapa organ dan sistem tubuh. Resiko kematian penyakit Lupus yang sangat tinggi dan diagnosanya yang sering terlambat yang berdampak psikologis pada penderita Lupus (yang selanjutnya disebut Odapus). Oleh karena itu diperlukan resiliensi, yaitu kemampuan untuk bertahan dan optimis untuk bertahan hidup dan sembuh. Penelitian ini bertujuan untuk melihat gambaran resiliensi pada para Odapus. Penelitian ini menggunakan pendekatan kualitatif. Subjek penelitian ini adalah delapan Odapus yang sedang menjalani proses strategi coping untuk bertahan dari penyakit Lupus. Hasil penelitian menunjukkan bahwa para Odapus masih membangun adaptasi dengan konstruksi yang negatif sehingga membutuhkan intervensi psikologis untuk meningkatkan kemampuan resiliensi para Odapus tersebut.
\end{abstract}

Kata kunci: Lupus, resiliensi

\section{PENDAHULUAN}

Penyakit Lupus merupakan penyakit autoimun kronis dimana terdapat kelainan sistem imun yang menyebabkan peradangan pada beberapa organ dan sistem tubuh. Mekanisme sistem kekebalan tubuh tidak dapat membedakan antara jaringan tubuh sendiri dan organisme asing (misalnya bakteri, virus) karena autoantibodi (antibodi yang menyerang jaringan tubuh sendiri) diproduksi tubuh dalam jumlah besar dan terjadi pengendapan kompleks imun (antibodi yang terikat pada antigen) di dalam jaringan (Syamsi Dhuha Foundation, 2003, dalam Syafi'i, 2012).

Berdasarkan data yang dikemukakan oleh Zubairi (dalam Syafi'i, 2012), setiap tahun sekitar 5-100 orang dapat terkena Lupus yang menyebabkan kematian. Berdasarkan data dari Yayasan Lupus Indonesia, jumlah penderita Lupus di Indonesia terus meningkat. Pada tahun 2010, terdapat 10.314 penderita Lupus; 9 dari 10 adalah perempuan (Anonim, 2010). Pada tahun 2012, penderita Lupus di Indonesia sudah mencapai 1,5 juta orang (Wartapedia, 2012). 
Penyakit Lupus sangat berbahaya karena dapat menyebabkan kematian, terutama penyakit Lupus berat yang menyerang ginjal, otak, paru, dan jantung. Penyakit Lupus umumnya menyerang individu berusia 15-44 tahun yang dalam keadaan sehat (Agnesa, 2009). Manifestasi penyakit Lupus pada tiap orang berbeda-beda, berubah dari waktu ke waktu, dan terkadang berlangsung cepat. Pasien dengan Lupus (Odapus) berat, misalnya Lupus ginjal atau sistem saraf pusat (SSP), dan Odapus yang menderita lebih dari satu jenis penyakit autoantibodi cenderung memiliki gejala yang serius dan menetap. Odapus yang memiliki gejala ringan dapat terus mengalami gejala ringan atau berkembang menjadi lebih serius (Agnesa, 2009).

Tingginya resiko kematian penyakit Lupus dan diagnosa yang sering terlambat dapat menimbulkan dampak psikologis pada Odapus. Para Odapus harus menghadapi penurunan kondisi fisik dan membutuhkan daya adaptasi yang luar biasa supaya mampu bertahan hidup. Perubahan fisik yang terjadi berupa bercak-bercak kemerahan yang muncul pada wajah, rambut rontok, sensitif terhadap sinar matahari, tubuh mulai bengkak, kulit mulai bersisik dan mulai mengelupas, sariawan di sekitar mulut, rasa nyeri pada persendian tangan dan kaki, sampai pada bagian tubuh yang sulit untuk digerakkan. Perubahan fisik tersebut dapat menjadikan Odapus cemas, minder, gelisah, dan perasaan lain yang berkecamuk, terutama ketika harus bergaul dengan orang lain. Untuk itu penanganan psikologis diperlukan untuk membantu Odapus supaya memiliki perasaan optimis untuk bertahan hidup dan sembuh.

Kemampuan untuk bertahan hidup atau daya lentur terhadap situasi atau kondisi yang mengancam seperti penyakit, kehilangan pasangan, bencana ataupun musibah disebut sebagai resiliensi. Banaag (dalam Chandra, 2009) menyatakan bahwa resiliensi adalah suatu proses interaksi antara faktor individual dengan faktor lingkungan. Faktor individual berfungsi menahan perusakan diri sendiri dan melakukan konstruksi diri secara positif, sedangkan faktor lingkungan berfungsi untuk melindungi individu dan melunakkan kesulitan hidup individu.

Salah satu metode yang dapat digunakan untuk meningkatkan kemampuan resiliensi adalah letting go. Corey (2005) menggunakan istilah letting go dalam pengertian melepaskan, luka dan dendam, rasa bersalah, serta pola-pola yang merusak diri sendiri seperti pikiran, perasaan, dan perilaku. Zimberoff dan Hartman (2003) menggunakan istilah letting go sebagai teknik untuk menghadirkan kembali hal-hal yang tidak disadari supaya dapat diakses. Sedangkan Freshwater dan Robertson (2002) menggunakan letting go dalam terapi untuk melepaskan harapan yang tidak terealisasikan. Fortunas (2003) melakukan penelitian kualitatif untuk mengkaji efektivitas letting go secara lebih mendalam. Fortunas akhirnya menyimpulan bahwa proses letting go memiliki analogi dengan proses pemecahan masalah berkaitan dengan perubahan diri, yaitu mengajak klien untuk membebaskan dirinya dari suatu keadaan yang memerangkapnya.

Wolin dan Wolin (dalam Chandra, 2009) menjelaskan resiliensi sebagai ketrampilan coping saat individu dihadapkan pada tantangan hidup atau kapasitas individu untuk tetap sehat (wellness) dan terus memperbaiki diri (self repair). Ada dua kondisi yang dibutuhkan dalam rangka menjelaskan resiliensi pada kehidupan individu, yaitu: (a) terjadinya adaptasi dan perkembangan pada ketangguhan yang utama (significant adversity) atau ancaman; dan (b) fungsi dan perkembangan tetap berjalan dengan baik meskipun terdapat ketangguhan yang utama. Reivich dan Shatte (2002) menyatakan bahwa resiliensi mencakup tujuh komponen, yaitu: regulasi emosi, pengendalian impuls, optimisme, analisis penyebab masalah, empati, efikasi diri, dan peningkatan aspek positif. 
Menurut Grotberg (1995), ada beberapa faktor yang mempengaruhi resiliensi individu, antara lain: (a) $\boldsymbol{I} \boldsymbol{A m}$, yaitu kekuatan yang berasal dari dalam diri individu, seperti tingkah laku, perasaan, dan kepercayaan yang terdapat dalam diri seseorang. Faktor I am ini dibagi menjadi beberapa bagian, yaitu: bangga pada diri sendiri, perasaan dicintai dan sikap yang menarik, mencintai, empati, altruistik, mandiri dan bertanggung jawab; (b) I Have, yaitu salah satu aspek yang mempengaruhi resiliensi yang berasal dari luar, misalnya: struktur dan aturan rumah, role model, mempunyai hubungan; (c) I Can, yaitu salah satu faktor resiliensi yang berkaitan dengan kompetensi sosial dan interpersonal seseorang, meliputi: mengatur berbagai perasaan dan rangsangan, mencari hubungan yang dapat dipercaya, ketrampilan berkomunikas, mengukur temperamen diri sendiri dan orang lain, serta kemampuan memecahkan masalah. Individu yang beresiliensi harus memiliki tiga faktor tersebut, yaitu I am, I have dan I can. Individu yang hanya memiliki salah satu faktor saja tidak termasuk orang yang beresiliensi. Penelitian ini bertujuan untuk mengetahui gambaran resiliensi pada orang penyandang Lupus (Odapus).

\section{METODE}

Penelitian ini merupakan studi deskriptif yang menekankan pada kedalaman dan proses. Subjek penelitian ditentukan oleh peneliti berdasarkan teori, konstruk operasional, atau tujuan penelitian. Karakteristik subjek dalam penelitian ini adalah: subjek menyandang penyakit Lupus, sedang menjalani proses coping untuk mencapai proses resiliensi terhadap penyakitnya. Subjek penelitian berjumlah 8 orang.

Metode pengumpulan data yang digunakan adalah wawancara semi terstruktur, observasi dan self-monitoring. Observasi dilakukan terhadap: profil fisik dan penampilan responden, perilaku dan reaksi responden, cara bicara dan pemilihan bahasa responden, serta daya tangkap dan konsentrasi responden. Self-monitoring merupakan catatan yang ditulis oleh seseorang untuk mengamati sehingga mendapatkan pemahaman tentang dirinya sendiri. Format self-monitoring berisi pertanyaan tentang situasi, suasana hati/ pikiran, pikiran dan perilaku yang muncul saat situasi terjadi.

\section{HASIL DAN PEMBAHASAN}

Dari hasil wawancara terhadap delapan orang Odapus diperoleh gambaran mengenai proses resiliensi yang mereka jalani. Gambaran tentang bagaimana Odapus beradaptasi terhadap penyakitnya, diringkas dalam Tabel 1a dan Tabel 1b.

Orang yang menyandang penyakit Lupus akan bereaksi secara kuat karena situasi atau kondisi penyakit tersebut akan memunculkan ketakutan-ketakutan. Tingginya resiko kematian penyakit Lupus, perubahan kondisi fisik yang terus menurun, dan tuntutan dimilikinya daya adaptasi yang luar biasa agar mampu bertahan hidup akan menimbulkan dampak psikologis yang besar bagi Odapus. Reaksi Odapus secara psikologi, kognitif, dan perilaku pada dasarnya adalah reaksi untuk beradaptasi terhadap penyakit Lupus yang dideritanya. Namun tidak semua orang yang mencoba beradaptasi dengan penyakitnya, mampu beradaptasi dengan konstruksi positif, karena bagaimanapun Lupus dapat membuta seseorang merasa cemas, stress atau bahkan mengalami depresi.

Kemampuan sesorang untuk bisa mencapai resiliensi tergantung daya tahan adaptasinya, gambaran kepribadian diri, 
Tabel 1a.

Data rangkuman hasil wawancara terhadap Subjek 1-4

\begin{tabular}{|c|c|c|c|c|}
\hline Aspek & Subjek 1 & Subjek 2 & Subjek 3 & Subjek 4 \\
\hline \multicolumn{5}{|c|}{ Gambaran Kecenderungan Resilensi } \\
\hline $\begin{array}{l}\text { Riwayat } \\
\text { penyakit }\end{array}$ & $\begin{array}{l}\text { Subjek bercerita awal } \\
\text { mula didiagnosa } \\
\text { penyakit Lupus oleh } \\
\text { dokter ketika muncul } \\
\text { ruam kupu-kupu pada } \\
\text { wajahnya. }\end{array}$ & $\begin{array}{l}\text { Subjek menceritakan } \\
\text { awal mula didiagnosa } \\
\text { penyakit Lupus pada } \\
\text { Tahun } 2010 \text {, yaitu } \\
\text { didiagnosa sindrom } \\
\text { nefrotik. Kemudian pada } \\
\text { tahun } 2013 \text { saya } \\
\text { menjalani biopsi ginjal } \\
\text { dan diagnosanya } \\
\text { berkembang menjadi } \\
\text { autoimun yaitu 19A } \\
\text { Nefropathy dan Februari } \\
\text { 2013 didiagnosa Lupus } \\
\text { nefritis. }\end{array}$ & $\begin{array}{l}\text { Subjek menceritakan } \\
\text { ketika didiagnosa } \\
\text { penyakit Lupus, gejala } \\
\text { yang dialaminya saat itu } \\
\text { adalah berat badannya } \\
\text { turun drastis, perut sakit, } \\
\text { tidak datang bulan, } \\
\text { rambut rontok, tulang } \\
\text { sakit, dan sering sakit } \\
\text { kepala. }\end{array}$ & $\begin{array}{l}\text { Subjek mengalami SLE } \\
\text { sejak } 3 \text { tahun yang lalu. } \\
\text { Awal mulanya, subjek } \\
\text { sering sakit sakitan dan } \\
\text { hampir setiap bulan rawat } \\
\text { inap di Rumah Sakit. } \\
\text { Setelah dicari } \\
\text { masalahnya, akhirnya } \\
\text { didiagnosa mengalami } \\
\text { Lupus. }\end{array}$ \\
\hline $\begin{array}{l}\text { Usaha } \\
\text { penyembuhan }\end{array}$ & $\begin{array}{l}\text { Berobat ke dokter, } \\
\text { selalu tepat minum } \\
\text { obat, dan selalu } \\
\text { mematuhi apa saja } \\
\text { yang disarankan oleh } \\
\text { dokter. }\end{array}$ & $\begin{array}{l}\text { Berdoa memohon } \\
\text { kesembuhan, berobat, } \\
\text { menerapkan pola hidup } \\
\text { sehat secara fisik } \\
\text { maupun psikologis. }\end{array}$ & Berobat rutin ke dokter. & $\begin{array}{l}\text { Subjek rutin berobat ke } \\
\text { dokter, mengikuti terapi } \\
\text { akupuntur dan fisioterapi, } \\
\text { aktif mencari berbagai } \\
\text { informasi tentang Lupus } \\
\text { sehingga lebih paham dan } \\
\text { tahu cara penanganannya. }\end{array}$ \\
\hline \multicolumn{5}{|c|}{ Penilaian Subjek terhadap Penyakitnya } \\
\hline $\begin{array}{l}\text { Respon } \\
\text { psikologis } \\
\text { yang muncul }\end{array}$ & $\begin{array}{l}\text { Subjek memiliki } \\
\text { ketakutan jika } \\
\text { penyakitnya tidak bisa } \\
\text { sembuh dan tubuhnya } \\
\text { tiba-tiba drop. Subjek } \\
\text { sampai saat ini masih } \\
\text { sering panik, terutama } \\
\text { jika ada tanda sakit } \\
\text { fisik muncul atau } \\
\text { ketika tubuhnya drop } \\
\text { tiba-tiba. Rasa } \\
\text { paniknya muncul } \\
\text { karena ia cemas jika } \\
\text { sewaktu-waktu } \\
\text { penyakitnya tidak } \\
\text { tertolong lagi. Selain } \\
\text { itu subjek juga merasa } \\
\text { tidak percaya diri } \\
\text { karena merasa ada } \\
\text { perubahan bentuk } \\
\text { fisik, merasa kesepian } \\
\text { dan bingung. Perasaan } \\
\text { sepi dipicu karena ia } \\
\text { merasa sendiri } \\
\text { mengalami penyakit } \\
\text { tersebut. Subjek juga } \\
\text { sering menangis dan } \\
\text { mudah marah karena } \\
\text { merasa tidak berdaya } \\
\text { dengan penyakitnya } \\
\text { dan masih mencari } \\
\text { alasan-alasan atau } \\
\text { jawaban kenapa ia } \\
\text { bisa mendapatkan } \\
\text { penyakit tersebut. }\end{array}$ & $\begin{array}{l}\text { Sejak didiagnosa } \\
\text { menderita Lupus, subjek } \\
\text { mengalami banyak } \\
\text { perubahan fisik dan } \\
\text { psikologis dalam } \\
\text { hidupnya. Ia sering } \\
\text { murung dan sedih } \\
\text { karena merasa diagnosa } \\
\text { tersebut merupakan } \\
\text { bagian terberat dalam } \\
\text { hidupnya. Fisik yang } \\
\text { berubah dan mudah drop } \\
\text { karena pengaruh } \\
\text { penyakit Lupus } \\
\text { membuat karirnya } \\
\text { menjadi tertunda, } \\
\text { kegiatan sosial menjadi } \\
\text { terbatas, ekonomi / } \\
\text { kondisi keuangan } \\
\text { menurun drastis, dan } \\
\text { rencana pernikahan } \\
\text { gagal karena ditinggal } \\
\text { calon suami setelah tahu } \\
\text { subjek menyandang } \\
\text { penyakit Lupus. }\end{array}$ & $\begin{array}{l}\text { Subjek merasa tidak } \\
\text { nyaman dengan apa yang } \\
\text { sering dirasakan. Ketika } \\
\text { rasa sakit muncul, } \\
\text { kadang sangat menyiksa } \\
\text { dan membuatnya tidak } \\
\text { nyaman. Kondisi ini } \\
\text { berpengaruh pada } \\
\text { aktivitas kesehariannya. } \\
\text { Sebagai remaja yang } \\
\text { sedang tumbuh, subjek } \\
\text { merasa berbeda dengan } \\
\text { teman-teman remajanya. } \\
\text { Sakit yang dialami } \\
\text { menjadikannya sangat } \\
\text { membatasi aktivitas. } \\
\text { Tidak semua kegiatan } \\
\text { dapat dilakukannya. Hal } \\
\text { ini menjadikan subjek } \\
\text { sering murung/sedih, } \\
\text { malu kepada orang lain } \\
\text { dan merasa risih bila } \\
\text { orang lain mengetahui } \\
\text { sakit yang dideritanya. } \\
\text { Subjek juga menganggap } \\
\text { dirinya sebagai pribadi } \\
\text { pengecut, menjijikkan, } \\
\text { tidak menarik, dan tidak } \\
\text { layak dicintai. Reaksi } \\
\text { yang muncul adalah } \\
\text { bingung, tidak percaya } \\
\text { diri, dan menunjukkan } \\
\text { perilaku agresif. Selain } \\
\text { itu muncul perasaan } \\
\text { kesepian dan penuh } \\
\text { penyesalan. }\end{array}$ & $\begin{array}{l}\text { Subjek merasa tidak } \\
\text { nyaman pada setiap } \\
\text { dosen/orang dekat yang } \\
\text { mengasihaninya karena } \\
\text { Lupus yang dideritanya. } \\
\text { Subjek merasa lelah } \\
\text { menjalani hidup, merasa } \\
\text { kesepian dan tidak } \\
\text { percaya diri. Reaksi yang } \\
\text { sering muncul adalah } \\
\text { mudah panik, cemas bila } \\
\text { tidak mampu } \\
\text { menyelesaikan tugas } \\
\text { dengan baik, dan sering } \\
\text { menangis tanpa sebab. }\end{array}$ \\
\hline
\end{tabular}


Tabel 1a.

Data rangkuman hasil wawancara terhadap Subjek 1-4 (lanjutan)

\begin{tabular}{|c|c|c|c|c|}
\hline Aspek & Subjek 1 & Subjek 2 & Subjek 3 & Subjek 4 \\
\hline $\begin{array}{l}\text { Respon fisik } \\
\text { yang muncul }\end{array}$ & $\begin{array}{l}\text { Ketika ada tanda-tanda } \\
\text { tubuhnya mengalami } \\
\text { sakit, subjek sering } \\
\text { mengalami jantung } \\
\text { berdebar-debar karena } \\
\text { dipicu rasa khawatir } \\
\text { kalau penyakitnya } \\
\text { akan semakin parah. }\end{array}$ & $\begin{array}{l}\text { Subjek sering tegang, } \\
\text { pusing, dan mengalami } \\
\text { gangguan perut ketika } \\
\text { memikirkan } \\
\text { penyakitnya. Subjek } \\
\text { pada dasarnya sudah } \\
\text { menyadari bahwa pola } \\
\text { pikirnya dapat } \\
\text { mengakibatkan } \\
\text { penurunan kondisi fisik, } \\
\text { namun ia belum } \\
\text { menerima sepenuhnya } \\
\text { penyakitnya. }\end{array}$ & $\begin{array}{l}\text { Bila ada tanda-tanda } \\
\text { tubuhnya mengalami } \\
\text { sakit, maka subjek } \\
\text { merasakan sakit kepala } \\
\text { dan gangguan pada perut. }\end{array}$ & $\begin{array}{l}\text { Ketika ada tanda-tanda } \\
\text { tubuhnya mengalami } \\
\text { sakit, maka subjek } \\
\text { merasakan sakit kepala, } \\
\text { jantung berdebar-debar, } \\
\text { tegang, pusing, sangat } \\
\text { lelah, sukar konsentrasi, } \\
\text { dan pingsan. }\end{array}$ \\
\hline $\begin{array}{l}\text { Respon } \\
\text { kognitif }\end{array}$ & $\begin{array}{l}\text { Subjek masih sering } \\
\text { menganalisa atau } \\
\text { berpikir mengapa dia } \\
\text { yang mengalami } \\
\text { penyakit tersebut, } \\
\text { kapan akan sembuh, } \\
\text { dan kenapa orang lain } \\
\text { tidak ada yang } \\
\text { mendapat penyakit } \\
\text { Lupus. }\end{array}$ & $\begin{array}{l}\text { Subjek bercerita bahwa } \\
\text { saat ini banyak hal yang } \\
\text { sangat dipikirkan, } \\
\text { terutama ketakutan- } \\
\text { ketakutannya yang } \\
\text { masih belum dilepaskan. } \\
\text { Berbagai macam } \\
\text { ketakutan yang } \\
\text { dialaminya, diantaranya } \\
\text { takut mengalami gagal } \\
\text { ginjal, takut kesehatan } \\
\text { semakin menurun, takut } \\
\text { tidak bisa sehat kembali, } \\
\text { takut tidak bisa menikah, } \\
\text { takut tidak mempunyai } \\
\text { anak. }\end{array}$ & $\begin{array}{l}\text { Subjek masih sering } \\
\text { berpikir mengapa dia } \\
\text { yang harus menderita } \\
\text { sakit ini. Kondisi ini } \\
\text { sering memunculkan } \\
\text { reaksi merasa bersalah, } \\
\text { berdosa, menganggap } \\
\text { Tuhan jahat, dan muncul } \\
\text { rasa benci. Subjek juga } \\
\text { mengalami ketakutan bila } \\
\text { ada orang lain yang } \\
\text { mengetahui sakitnya saat } \\
\text { ini. }\end{array}$ & $\begin{array}{l}\text { Subjek sering berpikiran } \\
\text { ngeri, merasa tubuhnya } \\
\text { cacat, dan muncul } \\
\text { ketakutan-ketakutan. } \\
\text { Subjek takut tidak mampu } \\
\text { bertahan dengan Lupus, } \\
\text { tidak bisa memiliki } \\
\text { pendamping hidup, dan } \\
\text { kekurangan sahabat. }\end{array}$ \\
\hline $\begin{array}{l}\text { Situasi atau } \\
\text { keadaan } \\
\text { yang } \\
\text { membuat } \\
\text { subjek } \\
\text { tenang }\end{array}$ & $\begin{array}{l}\text { Dukungan keluarga } \\
\text { bisa membuat subjek } \\
\text { merasa bahagia dan } \\
\text { lupa akan keluhan } \\
\text { sakitnya, terutama } \\
\text { ketika berkumpul dan } \\
\text { bercanda bersama. }\end{array}$ & $\begin{array}{l}\text { Subjek menceritakan } \\
\text { dirinya bisa menjadi } \\
\text { lebih tenang ketika } \\
\text { berdoa atau } \\
\text { melaksanakan ibadah. }\end{array}$ & $\begin{array}{l}\text { Subjek merasa tenang } \\
\text { ketika orang tua tidak } \\
\text { membahas tentang } \\
\text { penyakitnya, tidak terlalu } \\
\text { menekan dan tidak } \\
\text { memaksa subjek untuk } \\
\text { menuruti keinginannya. } \\
\text { Subjek tertekan karena } \\
\text { merasa orangtuanya tidak } \\
\text { pernah mengerti apa yang } \\
\text { dirasakannya saat ini. } \\
\text { Subjek akan tenang bila } \\
\text { orangtua berhenti } \\
\text { mengatur hidupnya. } \\
\text { Selain itu subjek akan } \\
\text { tenang bila orangtua atau } \\
\text { orang yang sudah } \\
\text { mengetahui sakitnya ini } \\
\text { tidak menyebarkan ke } \\
\text { orang lain. } \\
\text { Subjek juga akan tenang } \\
\text { bila orang-orang tidak } \\
\text { mengasihaninya karena } \\
\text { subjek ingin meyakinkan } \\
\text { ke semua orang bahwa } \\
\text { dirinya kuat dan mampu } \\
\text { melewati ini semua. }\end{array}$ & $\begin{array}{l}\text { Subjek merasa tenang bila } \\
\text { berada dekat dengan } \\
\text { orang-orang yang } \\
\text { mencintai dan } \\
\text { mendukungnya. }\end{array}$ \\
\hline
\end{tabular}


Tabel 1a.

Data rangkuman hasil wawancara terhadap Subjek 1-4 (lanjutan)

\begin{tabular}{|c|c|c|c|c|}
\hline Aspek & Subjek 1 & Subjek 2 & Subjek 3 & Subjek 4 \\
\hline $\begin{array}{l}\text { Alasan } \\
\text { subjek untuk } \\
\text { bertahan }\end{array}$ & $\begin{array}{l}\text { Subjek masih memiliki } \\
\text { keinginan untuk } \\
\text { sembuh karena ingin } \\
\text { membahagiakan dan } \\
\text { membantu orang lain, } \\
\text { masih ingin } \\
\text { bermanfaat bagi } \\
\text { kelurga dan orang- } \\
\text { orang yang } \\
\text { membutuhkan. }\end{array}$ & $\begin{array}{l}\text { Subjek masih memiliki } \\
\text { keinginan untuk sembuh } \\
\text { karena masih memiliki } \\
\text { cita-cita untuk menikah } \\
\text { atau memiliki keluarga } \\
\text { yang bahagia dan bisa } \\
\text { bekerja lagi. }\end{array}$ & $\begin{array}{l}\text { Subjek masih memiliki } \\
\text { keinginan untuk sembuh } \\
\text { karena ingin } \\
\text { membuktikan bahwa dia } \\
\text { perempuan yang perkasa. } \\
\text { Dia ingin menjadi } \\
\text { perempuan yang kuat } \\
\text { sehingga tidak akan } \\
\text { dipandang lemah oleh } \\
\text { orang lain. }\end{array}$ & $\begin{array}{l}\text { Subjek masih memiliki } \\
\text { keinginan untuk sembuh } \\
\text { karena subjek adalah } \\
\text { orang yang kuat dan } \\
\text { memiliki keyakinan akan } \\
\text { mampu melewati masa } \\
\text { sulit sehingga keluar } \\
\text { sebagai pemenang. }\end{array}$ \\
\hline
\end{tabular}

Tabel $1 b$.

Data rangkuman hasil wawancara terhadap Subjek 5-8

\begin{tabular}{|c|c|c|c|c|}
\hline Aspek & Subjek 5 & Subjek 6 & Subjek 7 & Subjek 8 \\
\hline \multicolumn{5}{|c|}{ Gambaran Kecenderungan Resilensi } \\
\hline $\begin{array}{l}\text { Riwayat } \\
\text { penyakit }\end{array}$ & $\begin{array}{l}\text { Subjek awalnya } \\
\text { mengalami penurunan } \\
\text { kondisi fisik yang } \\
\text { ditandai dengan } \\
\text { pandangan mata yang } \\
\text { sering kabur, kulit } \\
\text { kepala sering sakit, } \\
\text { albumin sering tidak } \\
\text { tentu meningkatnya, } \\
\text { dan dada sakit untuk } \\
\text { nafas. Kondisi tersebut } \\
\text { terjadi sekitar } 1 \text { bulan. } \\
\text { Setelah ada diagnosa } \\
\text { dokter, subjek mulai } \\
\text { merasakan linu-linu di } \\
\text { persendian, terutama } \\
\text { bagian lutut, abses di } \\
\text { jari bagian kelingking, } \\
\text { demam tinggi, rambut } \\
\text { rontok, HB } \\
\text { drop/anemia (HB drop } \\
\text { sekitar 7,0 dan sulit } \\
\text { untuk dikontrol), } \\
\text { kondisi tubuh mudah } \\
\text { drop,dan menstruasi } \\
\text { yang sulit dikontrol. }\end{array}$ & $\begin{array}{l}\text { Awal mula mengalami } \\
\text { gangguan kesehatan } \\
\text { sejak November } 2012 \text {. } \\
\text { Berdasarkan serang- } \\
\text { kaian pemeriksaan, } \\
\text { subjek kemudian didiag- } \\
\text { nosa menderita Lupus } \\
\text { pada bulan Februari } \\
2013 \text {. }\end{array}$ & $\begin{array}{l}\text { Sebelum didiagnosa } \\
\text { penyakit Lupus, gejala } \\
\text { yang dialami adalah berat } \\
\text { badannya turun, rambut } \\
\text { rontok, muncul ruam- } \\
\text { ruam di wajah. }\end{array}$ & $\begin{array}{l}\text { Subjek didiagnosa Lupus } \\
\text { sejak November } 2009 . \\
\text { Gejalanya sudah mulai } \\
\text { muncul sejak tahun } 2005 \text {. } \\
\text { Ketika itu subjek hamil } \\
\text { yang kedua; keguguran } \\
\text { umur empat bulan, tahun } \\
2007 \text { hamil yang ketiga, } \\
\text { mengalami eklamsi. Pada } \\
\text { rentang waktu 2005-2007 } \\
\text { muncul gejala-gejala } \\
\text { Lupus, seperti ruam } \\
\text { merah di pipi, badan } \\
\text { sering ngilu, dan } \\
\text { trombosit sering drop. } \\
\text { Tahun } 2009 \text { mengalami } \\
\text { flare, serangan Lupus } \\
\text { hebat sampai tidak bisa } \\
\text { berjalan. }\end{array}$ \\
\hline $\begin{array}{l}\text { Usaha } \\
\text { penyembuhan }\end{array}$ & $\begin{array}{l}\text { Subjek menjalani } \\
\text { perawatan medis, } \\
\text { yaitu periksa dan } \\
\text { minum obat dari } \\
\text { dokter, rutin check up, } \\
\text { berusaha } \\
\text { mengkonsumsi } \\
\text { makanan sehat } \\
\text { termasuk menghindari } \\
\text { MSG, zat pengawet } \\
\text { dll. }\end{array}$ & $\begin{array}{l}\text { Subjek secara rutin } \\
\text { berobat dan kontrol ke } \\
\text { dokter. }\end{array}$ & $\begin{array}{l}\text { Subjek berobat rutin ke } \\
\text { dokter, mencari } \\
\text { informasi melalui } \\
\text { internet dan aktif dalam } \\
\text { organisasi Odapus untuk } \\
\text { berbagi pengalaman } \\
\text { dalam proses } \\
\text { penyembuhan. }\end{array}$ & $\begin{array}{l}\text { Subjek berobat ke dokter, } \\
\text { aktif dalam organisasi } \\
\text { Odapus untuk berbagi } \\
\text { pengalaman dalam proses } \\
\text { penyembuhan dan lebih } \\
\text { mendekatkan diri pada } \\
\text { Tuhan dengan aktif ikut } \\
\text { pengajian dan dzikir } \\
\text { bersama. }\end{array}$ \\
\hline
\end{tabular}


Tabel $1 b$.

Data rangkuman hasil wawancara terhadap Subjek 5-8 (lanjutan)

\begin{tabular}{|c|c|c|c|c|}
\hline Aspek & Subjek 5 & Subjek 6 & Subjek 7 & Subjek 8 \\
\hline \multicolumn{5}{|c|}{ Penilaian Subjek terhadap Penyakitnya } \\
\hline $\begin{array}{l}\text { Respon } \\
\text { psikologis } \\
\text { yang } \\
\text { muncul }\end{array}$ & $\begin{array}{l}\text { Subjek menjadi } \\
\text { pemurung, tidak } \\
\text { percaya diri, dan } \\
\text { merasa segala aktivitas } \\
\text { yang dijalankannya } \\
\text { menjadi sangat } \\
\text { membosankan. }\end{array}$ & $\begin{array}{l}\text { Subjek merasa } \\
\text { selalu tidak tenang; } \\
\text { sering gelisah bila } \\
\text { mengingat sakitnya, } \\
\text { dan menjadi } \\
\text { bingung dengan } \\
\text { dirinya sendiri. } \\
\text { Subjek juga merasa } \\
\text { risih dan cemas } \\
\text { dengan penilaian } \\
\text { orang lain terhadap } \\
\text { sakitnya. }\end{array}$ & $\begin{array}{l}\text { Subjek merasa tidak } \\
\text { nyaman dengan apa yang } \\
\text { sering dirasakan. Ketika } \\
\text { rasa sakit muncul, kadang } \\
\text { sangat menyiksa. Kondisi } \\
\text { ini mempengaruhi } \\
\text { aktivitasnya. Subjek } \\
\text { sebelumnya sangat aktif } \\
\text { sebagai wirausaha, namun } \\
\text { setelah didiagnosa Lupus, } \\
\text { subjek mulai membatasi } \\
\text { aktivitas untuk } \\
\text { menghindari kelelahan. } \\
\text { Subjek menjadi stres } \\
\text { dengan kondisinya. }\end{array}$ & $\begin{array}{l}\text { Subjek mengalami stres karena } \\
\text { penyakitnya langka, tiba-tiba } \\
\text { tidak bisa jalan dan } \\
\text { beraktivitas. Stres semakin } \\
\text { bertambah karena keluarga } \\
\text { besar juga menduga sakitnya } \\
\text { disebabkan santet sehingga } \\
\text { keluarga ada yang mendatangi } \\
\text { paranormal. Hal ini menjadikan } \\
\text { subjek depresi. Akibatnya } \\
\text { subjek sering mengeluh. Selain } \\
\text { itu, fisiknya yang semakin } \\
\text { lemah, sering drop, muka yang } \\
\text { berubah tembem (moon face) } \\
\text { menjadikan subjek sedih karena } \\
\text { anaknya bahkan mengatakan } \\
\text { wajah subjek seram seperti } \\
\text { hantu. }\end{array}$ \\
\hline $\begin{array}{l}\text { Respon } \\
\text { fisik yang } \\
\text { muncul }\end{array}$ & $\begin{array}{l}\text { Ketika ada tanda-tanda } \\
\text { tubuh mengalami sakit } \\
\text { maka subjek merasakan } \\
\text { gangguan buang air } \\
\text { besar dan sulit } \\
\text { konsentrasi. }\end{array}$ & $\begin{array}{l}\text { Ketika ada tanda- } \\
\text { tanda tubuh } \\
\text { mengalami sakit, } \\
\text { subjek merasakan } \\
\text { sakit kepala yang } \\
\text { tiba-tiba. }\end{array}$ & $\begin{array}{l}\text { Ketika ada tanda-tanda } \\
\text { tubuh mengalami sakit, } \\
\text { subjek merasakan } \\
\text { kepalanya sangat berat } \\
\text { bahkan sampai pingsan. }\end{array}$ & $\begin{array}{l}\text { Ketika ada tanda-tanda tubuh } \\
\text { mengalami sakit, subjek } \\
\text { merasakan pusing, kaki } \\
\text { bengkak, dan kram perut. }\end{array}$ \\
\hline $\begin{array}{l}\text { Respon } \\
\text { kognitif }\end{array}$ & $\begin{array}{l}\text { Kondisi yang dialami } \\
\text { subjek sering } \\
\text { memunculkan } \\
\text { ketakutan bila sakitnya } \\
\text { bertambah parah, } \\
\text { ketakutan kesulitan } \\
\text { keuangan karena biaya } \\
\text { berobat yang mahal. } \\
\text { Kondisi ini } \\
\text { memunculkan } \\
\text { ketakutan jika kondisi } \\
\text { keluarganya menjadi } \\
\text { tidak kondusif lagi. }\end{array}$ & $\begin{array}{l}\text { Subjek sering tidak } \\
\text { bisa mengontrol } \\
\text { pikiran sehingga } \\
\text { muncul ketakutan } \\
\text { tidak akan sembuh } \\
\text { dari sakitnya. }\end{array}$ & $\begin{array}{l}\text { Kondisi yang dialami } \\
\text { subjek ini menjadikannya } \\
\text { bertanya-tanya apa } \\
\text { maksud Tuhan } \\
\text { mengirimkan sakit Lupus } \\
\text { ini. Apakah ini hukuman, } \\
\text { azab, teguran, atau ujian } \\
\text { untuk naik kelas. }\end{array}$ & $\begin{array}{l}\text { Kondisi yang dialami subjek ini } \\
\text { menjadikannya bingung apakah } \\
\text { sakitnya ini disebabkan santet } \\
\text { atau karena sebab yang lain. } \\
\text { Subjek mengalami ketakutan } \\
\text { karena penyakitnya ini langka } \\
\text { dan menjadikannya tidak bisa } \\
\text { beraktivitas sama sekali. }\end{array}$ \\
\hline $\begin{array}{l}\text { Situasi } \\
\text { atau } \\
\text { keadaan } \\
\text { yang } \\
\text { membuat } \\
\text { subjek } \\
\text { tenang }\end{array}$ & $\begin{array}{l}\text { Subjek akan menjadi } \\
\text { tenang dan nyaman } \\
\text { saat berhasil sembuh } \\
\text { dan saat kondisi di } \\
\text { rumah kondusif, yaitu } \\
\text { ketika kakaknya tidak } \\
\text { protes lagi, bisa } \\
\text { menemukan solusi } \\
\text { dengan orang tua, ibu } \\
\text { tidak mendapat tekanan } \\
\text { dengan semua sikap } \\
\text { kakak yang membuat } \\
\text { muak dan anarkis. } \\
\text { Kondisi rumah yang } \\
\text { kondusif menjadikan } \\
\text { subjek tidak khawatir } \\
\text { dan takut dengan } \\
\text { keselamatan ibunya. }\end{array}$ & $\begin{array}{l}\text { Subjek merasa } \\
\text { tenang bila orang- } \\
\text { orang terdekat } \\
\text { mendukungnya } \\
\text { untuk bisa bertahan } \\
\text { dan sembuh. }\end{array}$ & $\begin{array}{l}\text { Subjek merasa tenang } \\
\text { ketika suami, anak-anak, } \\
\text { dan keluarga besarnya } \\
\text { memberikan support } \\
\text { penuh pada dirinya. }\end{array}$ & $\begin{array}{l}\text { Subjek merasa tenang ketika } \\
\text { suami, anak, dan keluarga } \\
\text { besarnya memberikan } \\
\text { dukungan penuh terhadap } \\
\text { dirinya. }\end{array}$ \\
\hline
\end{tabular}


Tabel 1b.

Data rangkuman hasil wawancara terhadap Subjek 5-8 (lanjutan)

\begin{tabular}{|c|c|c|c|c|}
\hline Aspek & Subjek 5 & Subjek 6 & Subjek 7 & Subjek 8 \\
\hline $\begin{array}{l}\text { Alasan } \\
\text { subjek } \\
\text { untuk } \\
\text { bertahan }\end{array}$ & $\begin{array}{l}\text { Subjek masih } \\
\text { memiliki keinginan } \\
\text { untuk sembuh karena } \\
\text { subjek ingin melihat } \\
\text { ibunya tenang dan } \\
\text { kondisi rumah } \\
\text { menjadi normal } \\
\text { kembali seperti saat } \\
\text { sebelum subjek } \\
\text { didiagnosa Lupus. }\end{array}$ & $\begin{array}{l}\text { Subjek masih memiliki } \\
\text { keinginan untuk } \\
\text { sembuh; Subjek yakin } \\
\text { memiliki kekuatan } \\
\text { sebagai pribadi yang } \\
\text { menarik dan penuh } \\
\text { perhatian sehingga dia } \\
\text { optimis orang-orang di } \\
\text { sekitarnya tetap akan } \\
\text { menerima dia } \\
\text { meskipun mengalami } \\
\text { sakit. Subjek juga } \\
\text { memiliki motivasi } \\
\text { untuk bisa berguna } \\
\text { bagi orang lain. }\end{array}$ & $\begin{array}{l}\text { Subjek masih memiliki } \\
\text { keinginan untuk sembuh } \\
\text { karena ingin } \\
\text { membahagiakan keluarga. } \\
\text { Harapan subjek untuk bisa } \\
\text { panjang umur dan bisa } \\
\text { sembuh semata-mata demi } \\
\text { keluarga. Subjek ingin } \\
\text { melihat anak-anaknya } \\
\text { tumbuh menjadi anak } \\
\text { sholeh dan menjadi } \\
\text { kebanggaan keluarga. }\end{array}$ & $\begin{array}{l}\text { Subjek masih memiliki } \\
\text { keinginan untuk sembuh karena } \\
\text { ingin membahagiakan suami } \\
\text { dan anak-anaknya yang telah } \\
\text { tulus dan ikhlas } \\
\text { mendukungnya. Suaminya } \\
\text { sangat sabar dan setia } \\
\text { mendampingi, anak-anaknya } \\
\text { juga sangat pengertian sehingga } \\
\text { tidak pernah meminta apapun } \\
\text { padanya, bahkan anaknya juga } \\
\text { merawat saat subjek sakit. } \\
\text { Melihat suami dan anak yang } \\
\text { setia merawatnya merupakan } \\
\text { obat yang paling utama bagi } \\
\text { subjek. }\end{array}$ \\
\hline
\end{tabular}

serta dukungan keluarga dan lingkungan. Karakter yang menonjol pada semua subjek adalah sosok yang cenderung mengontrol segala sesuatu agar berjalan dengan baik sehingga membuat mereka seperti kehilangan arah ketika menderita penyakit, sehingga merasa tidak memiliki apa-apa lagi. Karakter ini terbentuk dari latar belakang keluarga, yaitu dari pola asuh, pengalaman masa kecil, dan hubungan kedekatan dengan orang tua maupun saudara kandung. Mereka terbiasa memendam perasaan negatif daripada mengungkapkan kepada orang lain karena tidak ingin membebankan masalahnya kepada orang lain. Odapus dalam penelitian ini tidak ingin diketahui sedang memiliki masalah tertentu.

Berdasarkan hasil analisis data, terlihat gambaran kondisi subjek yang belum menunjukkan resiliensi yang optimal, yang digambarkan pada Gambar 1.

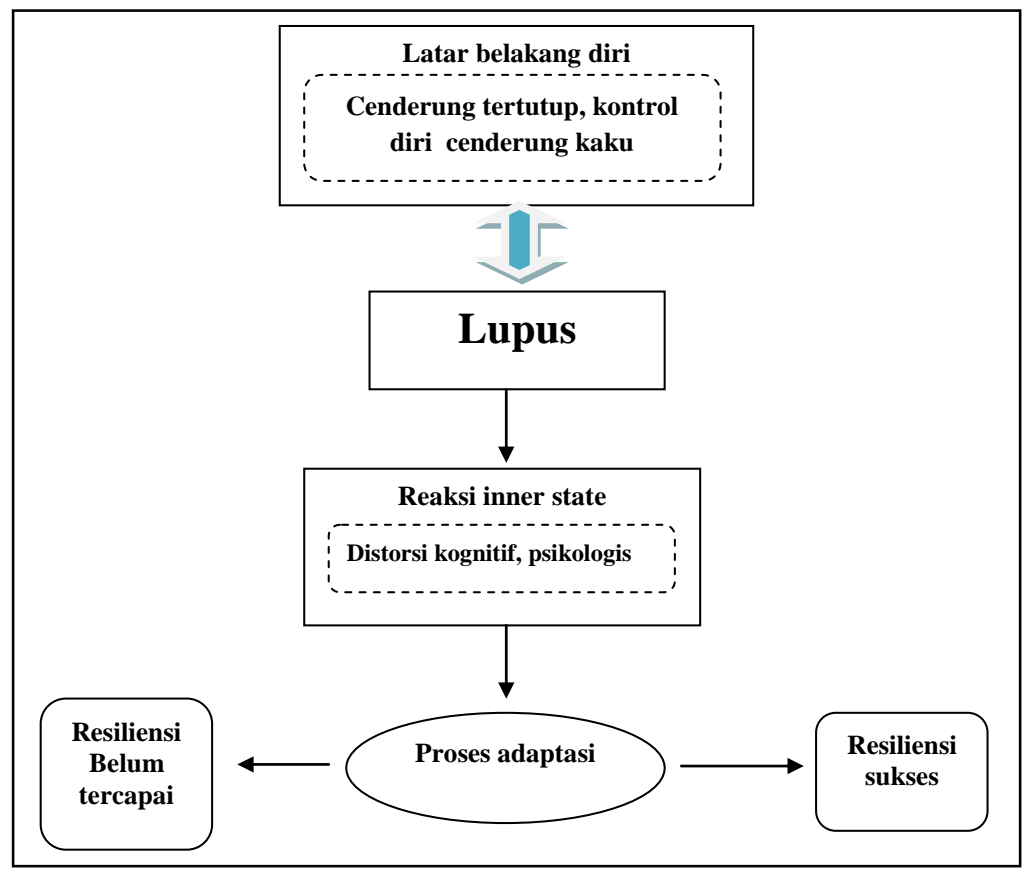

Gambar 1. Analisis Lintas Kasus 


\section{KESIMPULAN}

Berdasarkan analisis data yang dilakukan, dapat ditarik kesimpulan sebagai berikut:

a. Individu penyandang Lupus, cenderung berisiko mengalami kondisi emosional yang negatif seperti cemas, stres atau bahkan depresi. Reaksi tersebut sesungguhnya muncul karena mereka berusaha untuk berdaptasi. Ketika para Odapus membangun adaptasi dengan konstruksi yang negatif maka beresiko cenderung mengalami depresi, sedangkan jika konstruksi adaptasinya positif maka mereka dapat mencapai resiliensi yang optimal.

b. Gejala kondisi kejiwaan yang muncul pada penyandang Lupus, ditunjukkan antara lain:

- gejala emosional: merasa bersalah, merasa takut, tidak percaya diri, merasa tertekan, merasa sedih dan sering menangis.

- gejala kognitif: merasa pesimis, merasa tidak ada jalan keluar, ragu-

- ragu, merasa hidup tidak bermanfaat, merasa seperti pecundang.

- gejala motivasional: merasa tergantung, merasa tidak ingin menghadapi hari esok, malas beraktivitas dan malas beraktifitas.

- gejala perilaku: menjadi tidak produktif, kurang konsentrasi, dan aktivitasnya sedikit.

- gejala somatis: nafsu makan berkurang, sulit tidur, sering sakit, cepat lelah.

Penelitian selanjutnya disarankan melibatkan lebih banyak subjek dan dengan mempertimbangkan komposisi gender subjek, menggunakan alat-alat tes psikodiagnostika, serta menguji efektivitas intervensi lanjutan.

\section{DAFTAR PUSTAKA}

Agnesa, A. (2009). Makalah penyakit Lupus. Makalah. Tidak diterbikan. Purwokerto: Jurusan Ilmu Kesehatan masyarakat, Fakultas Kedokteran dan Ilmu-ilmu Kesehatan

Bowman, I. G. (2003). Exploring the retrospective experience of selfforgiveness in psychotherapy. Disertasi. Pretoria: Department of Psychology, University of Pretoria.

Chandra, S. (2009). Diunduh pada tanggal 30 Januari 2013 dari www.putrassyamsuri-blogspot.com/ 2009/ 02/ resiliensi.html

Corey, G. (2005). Theory and practice of counseling and psychotherapy. $7^{\text {th }}$ edition. Velmont: Brrooks/ColeThompson Learning

Fortunas, D. (2003). The experience of letting go: A phenomenological study. Disertasi. Pretoria: Department of Psychology, University of Pretoria.

Freshwater, D. \& Robertson, C. (2002). Emotion and needs. Buckingham: Open University Press.

Gow, K. M. (1999). Letting go: For physical, emotional, and spiritual health. Journal of Religion and Health,38(2), 155-156.

Grotberg, E. (1995). A guide to promoting resilience in children: Strengthening the human spirit. The Hague: Benard Van Leer Foundation.

Lewis, J. L. (2005). Forgiveness and psychotherapy: The prepersonal, the personal, and the transpersonal. The Journal of Transpersonal Psychology,37(2), 124-142. 
Reivich, K. \& Shatte, A. (2002). The resilience factor. New York: Broadway Books.

Syafi'i, M. (2012). Dukungan Sosial dala Membangun Keterampilan Resiliensi pada Penderita Lupus. Skripsi. Tidak diterbitkan. Surabaya: Program Studi Psikologi, Fakultas Dakwah Institut Agama Islam Negeri Sunan Ampel.
Wartapedia. 2012. LUPUS: Penderita Lupus Di Indonesia Capai 1,5 Juta Orang. Diunduh pada Tanggal 1 Februari 2013 dari www. wartapedia.com/2012/

Zimberoff, D. \& Hartman, D. (2003). Transpersonal Psychology in HeartCentered Therapies. Journal of HeartCentered Therapies, 6(1), 123-144. 